Journal of Pediatric Gastroenterology and Nutrition Publish Ahead of Print

10.1097/MPG.0000000000001821

\title{
Young child formula - A position paper by the ESPGHAN Committee on Nutrition
}

ESPGHAN Committee on Nutrition: \#Iva Hojsak, đIIJiri Bronsky, đCristina Campoy,

*Magnus Domellöf, ${ }^{+}$Nicholas Embleton, \&\&Nataša Fidler Mis, $ф$ Jessie Hulst,

${ }^{\circ \circ}$ Flavia Indrio, £Alexandre Lapillonne, \&Christian Molgaard, $\varnothing \notin$ Rakesh Vora,

$\S \S$ Mary Fewtrell

Children's Hospital Zagreb, University of Zagreb School of Medicine, University J.J.

Strossmayer School of Medicine Osijek, Croatia; IITI Department of Paediatrics, University

Hospital Motol, Prague, Czech Republic; II Department of Paediatrics, University of Granada,

Spain; $\not$; Department of Clinical Sciences, Pediatrics, Umeå University, Umeå, Sweden; ${ }^{+}$

Newcastle Neonatal Service, Newcastle Hospitals NHS Trust and Newcastle University,

Newcastle upon Tyne, UK; \&\&Department of Gastroenterology, Hepatology and Nutrition,

University Children's Hospital, University Medical Centre Ljubljana, Slovenia; $₫$ Erasmus

MC, Sophia Children's Hospital, Rotterdam, The Netherlands; $\$++^{\circ}$ Ospedale Pediatrico

Giovanni XXIII University of Bari Italy; $£$ Paris Descartes University, APHP Necker-Enfants

Malades hospital, Paris, France and CNRC, Baylor College of Medicine, Houston, Texas;

\&Department of Nutrition, Exercise and Sports, University of Copenhagen, and Pediatric

Nutrition Unit, Copenhagen University Hospital, Rigshospitalet, Denmark; $₫ \varnothing$ Leeds teaching hospitals NHS trust, Leeds, UK; §§ Childhood Nutrition Research Centre, UCL GOS Institute of Child Health, London, UK;

Secretary of CoN: \#Iva Hojsak

Chair of CoN: §§Mary Fewtrell 


\section{Corresponding author:}

Iva Hojsak, MD, PhD

Referral centre for paediatric gastroenterology and nutrition,

Children's hospital Zagreb

Klaićeva 16, 10000 Zagreb, Croatia

Phone: +38514600130

Fax: +38514600160

Email:ivahojsak@gmail.com

\section{Conflict of interest related to the manuscript:}

- Jiri Bronsky - honoraria for lectures and travel support from Nutricia and Nestlé

- Cristina Campoy - research funding from ORDESA Laboratories, S.A.

- Magnus Domellöf - lecture fees from Nestlé and Semper

- Mary Fewtrell - honoria for lectures (Nestlé Nutrition Institute) and editing book on growth (Danone)

- Nicholas Embleton - speaker fees and research funding from manufacturers of infant milk formula (Nestle and Danone Baby Nutrition) for studies in preterm infants

- Alexandre Lapillonne - lecture fees from Nestlé and Mead Johnson Nutrition

- Other authors declared no COI related to this topic

Funding of the study: None

Key words: toddler's milk, growing up milk, toddlers, follow-on formula

DISCLAIMER: ESPGHAN is not responsible for the practices of physicians and provides guidelines and position papers as indicators of best practice only. Diagnosis and treatment is at the discretion of physicians. 


\section{Abstract}

Young child formulae (YCF) are milk-based drinks or plant protein-based formulae intended to partially satisfy the nutritional requirements of young children aged 1-3 years. However, although widely available on the market, their composition is not strictly regulated and health effects have not been systematically studied. Therefore, the ESPGHAN Committee on Nutrition $(\mathrm{CoN})$ performed a systematic review of the literature to review the composition of YCF and consider their role in the diet of young children. The review revealed limited data but identified that YCF have a highly variable composition, which is in some cases inappropriate with very high protein and carbohydrate content and even high amounts of added sugars. Based on the evidence, ESPGHAN CoN suggests that the nutrient composition of YCF should be similar to that of follow-on formulae with regards to energy and nutrients that may be deficient in the diets of European young children such as iron, vitamin D and poly-unsaturated fatty acids (n-3 PUFAs); while the protein content should aim towards the lower end of the permitted range of follow-on formulae if animal protein is used. There is data to show that YCF increase intakes of vitamin D, iron and n-3 PUFAs. However, these nutrients can also be provided via regular and/or fortified foods or supplements. Therefore, ESPGHAN CoN suggests that based on available evidence there is no necessity for the routine use of YCF in children from 1-3 years of life, but they can be used as part of a strategy to increase the intake of iron, vitamin D and n-3 PUFA and decrease the intake of protein compared to unfortified cow's milk. Follow-on formulae can be used for the same purpose. Other strategies for optimizing nutritional intake include promotion of a healthy varied diet, use of fortified foods, and use of supplements.

Key words: toddler's milk, growing up milk, toddlers, follow-on formula 


\section{What is known:}

- There is no international legal definition or compositional criteria for young child formula.

- The composition of currently available young child formulas on the European market differs significantly.

- There is overall limited evidence on the health effects of young child formula on the children.

\section{What is new:}

- The article presents critical literature review on the role of young child formula for nutrition in European children.

- Based on available evidence ESPGHAN Committee on Nutrition does not recommend routine use of YCF in children from 1-3 years of life. However, they can be used as part of a strategy to increase the intake of iron, vitamin D and n-3 PUFA and decrease the intake of protein compared to unfortified cow's milk. 


\section{Introduction}

Toddler's milk, growing up milk or formula for young children are synonyms referring to milk-based drinks or plant protein-based formulae intended to partially satisfy the nutritional requirements of young children aged 1-3 years (1). The European Food Safety Authority (EFSA) recommends the use of the term "young child formula" (YCF) because this age group (young child) is strictly defined as from 1-3 years. Furthermore, as YCF may not necessarily contain animal protein it is suggested to use term "formula" rather than "milk". The term "growing-up" should not be used because it implies a specific impact on growth. In order to unify the terms, the European Society for Paediatric Gastroenterology, Hepatology and Nutrition (ESPGHAN) Committee on Nutrition (CoN) also recommends the use of the term YCF.

YCF have been available in Europe for more than two decades and their use is increasing (2), however product information is mainly provided by manufacturers whilst scientific reviews on their necessity or effects are limited. Furthermore, there is no international legal definition or compositional criteria for these products and their availability and regulation differs between European countries (2).

Based on the EFSA report published in 2013, there are hundreds of YCFs present on the EU market, with the highest number in France $(n=34)$, Spain $(n=32)$ and Italy $(n=24)$, and the lowest in Scandinavian countries, Sweden $(n=2)$ and Denmark $(n=0)(1)$.

Regarding regulation within the EU, YCF were classified as foods intended for particular nutritional uses (so-called "dietetic foods") in 17 EU countries (Bulgaria, Cyprus, Czech Republic, Croatia, Finland, France, Germany, Hungary, Ireland, Italy, Lithuania, Netherlands, Poland, Portugal, Romania, Slovenia and Sweden) and Norway (1). This legislation, however, was repealed in 2013 with effect from $20^{\text {th }}$ of July 2016. Since that date the FSG (Foods intended for Specific Groups) Regulation is applicable and the concept of "dietetic foods" 
ceased to exist (1). All YCF placed on the market as "dietetic foods" are now classified as normal foods, fortified with certain nutrients and targeting a specific sub-group of the population (young children). This classification was already in use in $10 \mathrm{EU}$ countries (Austria, Belgium, Estonia, Greece, Latvia, Luxembourg, Malta, Slovakia, Spain, United Kingdom) (1).

Recommendations from relevant paediatric and/or nutritional societies throughout Europe also differ. The German Federal Institute for Risk Assessment (BfR) report from 2014 concludes that after the age of 1 year, in general, there is no nutritional necessity for specific foods, meaning that young children should adapt to a diverse diet including fresh ingredients consumed within the family (3). The same report recognizes that YCF can increase the supply of some micronutrients in this specific population, nevertheless they are not better for these purposes than other fortified foods, or the early, adequate introduction of meat/fish in the diet of young children or use of supplements. The German Society of Paediatrics and Adolescent Medicine (DGKJ) recently adopted updated guidance stating that YCF are not necessary but may contribute to improving nutrient supply of the omega-3 polyunsaturated fatty acids (n-3 PUFA), iron, vitamin D and iodine (4). It further recommends specific compositional requirements for $\mathrm{YCF}$.

The medical community in France, specifically paediatricians, support the consumption of YCF for the period from 12 to 36 months in an amount of $500 \mathrm{ml}$ per day (5). A Belgian consensus-statement on growing-up milks for children 12-36 months concludes that it is possible to meet nutritional requirements without $\mathrm{YCF}$, however present diets offered to toddlers often do not meet nutrient requirements and, therefore, supplemented foods could be helpful and YCF is one option (6). The EFSA report from 2013 concludes that there is no unique role of YCF in the provision of critical nutrients for young children in Europe and 
therefore they cannot be considered as a necessity compared with other foods that may be included in the normal diet of young children (7).

An additional problem is the lack of compositional guidelines for YCF. Recently, an International Expert Group Coordinated by the Nutrition Association of Thailand and the Early Nutrition Academy provided recommendations for composition of YCF (8). Similarly, other groups of authors have published their recommendations on the composition of YCF (9).

The aim of this ESPGHAN CoN position paper is to critically review the available evidence on the role of YCF for nutrition in children, to consider existing recommendations for their content and to propose recommendations for European children.

Nutritional intake in European toddlers - current situation

Although recommendations for adequate nutritional intakes in young children are available, data on actual intake in toddlers are limited (10-15). A recent systematic review examined macro- and micronutrient intakes in the paediatric population (8). This review of 5 studies from 3 European countries (Ireland, France and Norway) (10-14) identified that alpha linolenic acid, iron and vitamin D intakes in particular were often insufficient. Similarly, EFSA mentions that dietary intakes in children from 1 to 3 years of age of vitamin D, iron, $n$ 3 PUFA and iodine are below requirements, and that particular attention should be paid to ensure an appropriate supply (7).

These deficiencies could be addressed by several approaches, including dietary counselling, supplements and fortified foods, and specific formula including follow-on formula and YCF (7). It should be mentioned that although recommended intakes for these nutrients were not met, no nutritional cases of rickets were detected within otherwise healthy European children (16). 


\section{Methods}

The databases Medline (via PubMed) and Cochrane were searched for keywords for publications up to January 2017. The following key terms were used (words in the title or abstract of the manuscript): ("toddler" OR "growing-up" OR "growing up" OR "young child" OR “young-child") AND ("milk" OR “formula" OR "diet”). The searches were limited to human studies. An age filter to restrict the search to children (0-18 years) was applied. All types of papers, including original papers, reviews, recommendations and guidelines were considered. Furthermore, the reference list from all relevant papers was also searched. The search was limited to English language manuscripts and only published data were considered. The reference lists of identified studies and key review articles, including previously published reviews, were searched.

Outcomes were determined that may identify any possible beneficial effect of YCF, and to review available data on the composition of YCF.

Recommendations were formulated and discussed in a total of 3 face to face meetings which were held in Paris, Newcastle and Prague. Between meetings CoN members interacted by iterative e-mails. All disagreements were resolved by discussion until a full consensus was reached for every statement.

\section{Composition}

The composition of currently available YCF on the market differs significantly. The majority (96\%) are based on cow's milk, and others include goat's milk and soy protein (1). Table 1 provides the composition of $244 \mathrm{YCF}$ which are available on the EU market based on EFSA and AINIA (Asociación de Investigación de la Industria Agroalimentaria) reports; and the composition of 234 YCF based on cow's milk; together with the composition of cow's milk and proposed composition of follow-on formula (1, 17-19). 
YCF was designed as an alternative to cow's milk or breast milk and aimed to further improve nutritional status in toddlers by adding nutrients which are generally low (or lacking) in the diet. However, compared to infant and follow-on formula for which the composition is defined by regulatory agencies, the composition of YCF is not defined $(1,20)$. It is difficult to make compositional recommendations for these products for several reasons; children gradually increase their intake and diversity of regular foods after the age of 6 months and the timing and duration of transition from complementary feeding to regular 'family' food differs. During this period breastmilk and/or formula milk consumption also decreases. Second, although recommendations for adequate nutritional intakes for young children are available, data on actual intake in toddlers, as presented above, are limited to only a few reports (10-14). Therefore, the scientific basis on which to define the composition of YCF, in terms of the 'nutrient gaps' that need to be addressed, is extremely limited and depends on the group or population of infants.

Our systematic search found two papers which proposed the composition of YCF; one of these was a detailed and comprehensive review prepared by the International Expert Group coordinated by the Nutrition Association of Thailand and Early Nutrition Academy (8). A second, much shorter, international report was produced by a panel comprised of several nutritional experts which was hosted and funded by a formula manufacturer and has several limitations; it is more general, some proposed limits are significantly different to follow-on formula and breast milk, and overall the methods are not clearly presented (9).

When discussing the composition of YCF some aspects of young children nutrition should be taken into account; first there is an overconsumption of energy dense foods and increasing obesity rates in European populations, and there is some evidence for an association between early high protein intake and a higher risk of obesity later in life $(21,22)$. Second, there is generally a lower than recommended intake of n-3 PUFA, iron and vitamin D (10-14). 
Therefore, it would be of interest to determine whether YCF intake could correct (and to what extent) some of these deficits as compared to cow's milk or follow-on formula. Regarding energy intake, if we assume a similar intake of YCF to cow's milk (4-6), then the overall energy content of the YCF should not exceed the energy content of whole fat cow's milk (68 $\mathrm{kcal} / 100 \mathrm{ml})$ and follow-on formula $(60-70 \mathrm{kcal} / 100 \mathrm{ml})(9,23)$. YCF currently available on the European market have energy contents from 50 to $81 \mathrm{kcal} / 100 \mathrm{ml}$ (median $67 \mathrm{kcal} / 100$ $\mathrm{ml}$ ) (1). This means that a child who receives $300 \mathrm{ml}$ of different YCF could receive between 150 and $240 \mathrm{kcal}$. Furthermore, unlike in resource-poor countries, in European populations there is generally a higher likelihood of energy excess than undernutrition (15), thus energy content should not exceed the energy content of full fat cow's milk or follow-on formula. However, the ideal energy content for YCF designed for European infants may be too low for resource-poor countries with a higher incidence of undernutrition.

A second nutrient which may be overconsumed in European children is protein. There is limited evidence that excessive intake of protein during infancy increases the later risk for obesity (21). Furthermore, intake of protein in some European toddlers is much higher than recommended $(6,15,24)$. Taking that into account, the amount of protein in YCF should be reduced to the amount in infant formula similar to breast milk. Previous reports stated that YCF should contain a minimum $1.6 \mathrm{~g}$ of animal protein/100 kcal (8). The amount of protein in YCF available on European market varies significantly (up to $6.7 \mathrm{~g} / 100 \mathrm{kcal}$; although it is not mentioned whether the protein source is animal or plant), and the median is $2.6 \mathrm{~g} / 100$ kcal, although the majority of YCF have a lower protein content than regular cow's milk (4.8 $\mathrm{g} / 100 \mathrm{kcal})$ (1). In general, children receiving YCF have a lower intake of protein compared to children taking cow's milk (10), yet, if cow's milk were replaced with YCF, protein intake would not decrease below $15 \%$ of total energy intake (6). As previously mentioned, it is also of concern that even the median $(2.6 \mathrm{~g} / 100 \mathrm{kcal})$ was higher than the upper level 
recommended by EFSA for follow-on formula $(2.5 \mathrm{~g} / 100 \mathrm{kcal})$. All of these points suggest the need to lower the protein content of YCF towards the lower limit permitted in follow-on formula (1.6 g/100 kcal for products based on intact animal protein) (19).

Overall the amount of carbohydrate in YCF is similar to that in follow-on formula, and much higher than in cow's milk. The problem is, however, the amount of added sucrose which is very high in some YCF (up to $10.4 \mathrm{~g} / 100 \mathrm{kcal}$ ). There are data showing that YCF available on Asian markets with added carbohydrates (glucose or corn syrup solids, maltodextrins, sucrose, lactose and fructose were the most common additives) increase glucose and insulin response significantly more than regular cow's milk (25). There is no need to add sugars other than lactose in amounts naturally present in milk $(8,26)$. Preferably, no free sugars should be added to products for children up to 2 years of age and their amount should be limited to < $5 \%$ of total energy intake in children above 2 years (26).

A possible beneficial effect of YCF is the provision of nutrients that are often lacking in the diet of European children; alpha linolenic acid, vitamin D and iron. These deficits are largely due to the very low content (vitamin D, iron, alpha-linolenic acid) of these nutrients in nonsupplemented cow's milk (7).

The median content of alpha linolenic acid in YCF is $103 \mathrm{mg} / 100 \mathrm{kcal}$ which is in the range recommended for follow-on formula. However, around $4 \%$ of all YCF have very low levels of alpha linolenic acid (7). Similarly, the median content of iron and vitamin D in YCF is within the recommended range for follow-on formula. Interestingly, none of the YCF have iron levels below the lower limit recommended for follow-on formulae and only $1.3 \%$ have a vitamin D content below this level (7). In contrast, non-supplemented cow's milk is poor source of iron and vitamin D.

In summary, the biggest concern is the significant differences in the composition of available YCF. Specifically, some YCF available on the European market have a high protein content, 
added sweeteners, taste modifiers, different amounts of vitamins and iron, and are without long chain polyunsaturated fatty acids (6).

Based on currently available data and taking into account the composition of breast milk there is no evidence which would support a significantly different composition of YCF compared to follow-on formulae used for infants after 6 months of age in European populations. This is mainly supported by the data revealing that European toddlers frequently have inadequate intakes of iron, vitamin D and n-3 PUFA which are all added to follow-on formula in adequate amounts to prevent deficiency (17). Based on the EFSA statement, formulae consumed during the first year of life can also be used in young children (1). Indeed, this was the basis for the EFSA Panel's on Dietetic Products, Nutrition and Allergies (NDA) decision not to propose specific compositional criteria for formulae consumed after one year of age (17). In order to assure good quality of all products, currently the CODEX ALIMENTARIUS is in the process of developing a regulation for the composition of YCF, to which ESPGHAN is actively contributing (27).

After reviewing the literature, albeit limited, the ESPGHAN CoN found no reason why follow-on formulae could not be used beyond infancy, nor any rationale for the composition of YCF being different from that of follow-on formulae, although the protein content should be towards the lower permitted level in follow-on formulae. However, if YCF is considered as a substitute for cows' milk, a simpler composition may be proposed; essentially fortified milk with only a few key nutrients specified, such as iron, vitamin D and n-3 PUFA. This approach would presumably have the theoretical advantage of reducing the production costs of YCF. Furthermore, regulation is needed not only to propose which nutrients should be added, but also to prevent and limit addition of unwanted components (eg. free sugars, flavourings). Health effects 
There is limited evidence on the effect of YCF on health outcomes in toddlers. Systematic reviews of the literature identified 6 RCTs published in 8 scientific papers which evaluated either the effect of YCF compared to cows' milk (28-32) or red meat (29-31), high vs low glycaemic index formula (33), YCF supplemented with symbiotic (34) or prebiotics and LCPUFAs (35) versus non-supplemented YCF and 9 cross sectional studies (Table 2).

A New Zealand study that tested risk factors for low vitamin D concentrations, found that one of the poor prognostic factors was not drinking YCF (36). A RCT also performed in New Zealand showed that intake of YCF supplemented with vitamin D and whole milk supplemented with vitamin D significantly decreases the proportion of children with vitamin D deficiency compared to children who were supplemented with meat (30). There was no difference in the vitamin D levels between the milk groups (30).

The KiMi trial, a German double blind RCT, compared vitamin D-fortified YCF $(2.85 \mu \mathrm{g} / 100$ $\mathrm{ml}$ ) with semi skimmed cow's milk without added vitamin D (28). Daily consumption of fortified YCF contributed to the prevention of an otherwise frequently observed decrease in serum 25-hydroxyvitamin D concentration during winter. Furthermore, a recently published multicentre European RCT found that supplementation with YCF significantly increases vitamin D serum levels and decreases the risk of vitamin D deficiency compared to cow's milk (32).

An RCT which determined the efficacy of an increased intake of red meat, or the consumption of iron-fortified YCF compared to regular cow's milk on iron status found that YCF significantly increased ferritin levels in toddlers (29). However, levels remained the same in the red meat group and decreased in the regular cow's milk group. There was no effect on the change in the prevalence of suboptimal iron status in healthy non-anaemic 12-24 month old children, although the fortified milk group was not powered sufficiently to detect this (29). Very recently, a multicentre European RCT (32) showed that those children 
randomized to cow's milk had a significant increase in iron deficiency (from 11.9\% at baseline to $29.6 \%$ at the end of intervention) in contrast to those randomized to YCF in whom the incidence was unchanged $(14.3 \%$ to $13.9 \%)$. However, due to the very small number of children with iron deficiency anaemia (4\% in cow's milk and $0 \%$ in YCF), this study was underpowered to differences in this outcome.

For YCF with synbiotics (34) and prebiotics in combination to LCPUFA (35) data are too limited to draw conclusions.

A cross-sectional Irish study found that children older than 12 months of age already eat a variety of foods and cow's milk was not the main source of nutrients (13). This study included children with an average daily total milk intake of at least $300 \mathrm{~g}$ per day who were stratified into two groups: those consuming >100 g YCF/day together with cow's milk or consuming cow's milk only. While average total daily energy intakes were similar in both consumers and non-consumers of $\mathrm{YCF}$, intakes of protein, saturated fat, and vitamin $\mathrm{B}_{12}$ were lower and intakes of carbohydrate, dietary fibre, iron, zinc, vitamins C and D were higher in consumers of YCF. For children consuming cow's milk only, 59\% had inadequate intakes of iron and $98 \%$ of vitamin D; these proportions were much lower in consumers of YCF (none and 69\%, respectively) meaning that consumption of YCF reduced the risk of inadequate intake of iron and vitamin D, two nutrients frequently lacking in the diets of young children (13). Similarly, a computer modelling study using cross-sectional data from the UK found that use of YCF with a decrease in cow's milk consumption might be the most effective way to achieve adequate nutritional intake (37).

Very recently, a systematic review and meta-analysis evaluated the role of fortified milk on growth and other biochemical markers (38). This review did not limit its search to YCF but included all fortified milks (including regular fortified cow's milk) and included an age limit of children in some studies that was less than one year old. Altogether 15 RCTs were 
included. Fortification varied from iron, zinc, vitamins, essential fatty acids, to pre- and/or probiotics and outcomes were weight and height gain and iron status. This systematic review concluded that fortified milk compared to control milk had minimal effects on weight gain (mean difference $=0.17 \mathrm{~kg} ; 95 \%$ CI $0.02-0.31 \mathrm{~kg}$ ) however most of included studies are from developing countries. The risk of anaemia was reduced in fortified milk groups $(\mathrm{OR}=0.32$; 95\% CI 0.15-0.66) compared with control groups. However, there were no significant effects on height gain, changes in body composition or haemoglobin concentration.

To conclude, reports from Europe do not suggest significant deficits in the nutritional intake of children except for iron, vitamin D and n-3 PUFAs. Whilst EFSA concluded that YCF are one way to increase intake of these nutrients they are not the only solution (1) and there are other efficient alternatives such as fortified cow's milk, fortified cereals and cereal-based foods, supplements or the early introduction of meat and sea fish into complementary feeding with continued regular consumption of these foods $(1,7)$.

Limited available evidence shows that the use of YCF can increase vitamin D intake, but YCF are not superior to supplemented regular cow's milk. Their intake can also increase ferritin levels and reduce iron deficiency, but the clinical relevance of this effect is not clear. No clinical studies were identified regarding the effect of YCF on the status of other nutrients.

\section{Disadvantages of YCF}

There are no published adverse effects associated with YCF. However, besides the already mentioned lack of recommendations and consequent high variability in YCF composition there are other possible disadvantages which include a continued preference for liquids in the diet (this may impact on control of satiety), a reduced interest in other ("regular") food with increased interest for YCF, and the potential for suggesting to parents and caregivers that 
manufactured foods for young children are a safer or healthier choice for meeting nutritional requirements $(2,6)$.

Lastly, intake of YCF may result in a significant additional financial burden on the family compared to normal family foods including cow's milk (6). However, a comparison of the relative costs of different strategies (e.g. healthy varied diet, enriched foods, follow-on formula, supplements, YCF) for meeting nutrient requirements for young children has not yet been performed.

Marketing and labelling

One-third of the global spend on milk formula for infants and young children is attributed to YCF, making it the largest single milk type in this category (39). Evidence shows that advertisements for YCF are perceived by parents as promoting formula in general so they are considered collectively as formula - infant formula, follow-on formula and YCF (39). This is mainly attributed to the use of brand advertising, meaning that all 3 types of formula appear similar to consumers. Because of this, the advertising of YCF may contribute to public perceptions around the use of, and potential benefits from, milk formula (compared to breast feeding) in general. Since 2016, WHO regards YCF as breast milk substitutes (40), with the consequence that these products should be subject to the WHO International Code of Marketing of Breast-milk Substitutes (41). Regardless of advertising, ESPGHAN CoN considers that it is still important that parents understand the difference between milk formulae used in infancy compared to YCF, because milk contributes less to the nutrient intake of a toddler than a younger infant. 


\section{Conclusions and recommendations}

- Breastfeeding should be recommended as part of a healthy diet after the first year of life if mutually desired by mother and child.

- In order to unify terms ESPGHAN CoN endorses the term young child formula (YCF) proposed by EFSA in 2013 for all formula specifically designed for children from 1 to 3 years of age.

- Based on available evidence there is no necessity for the routine use of YCF in children from 1-3 years of life, but they can be used as part of a strategy to increase the intake of iron, vitamin D and n-3 PUFA and decrease the intake of protein compared to unfortified cow's milk. Follow-on formulae can be used for the same purpose.

- Other strategies for optimizing nutritional intake include promotion of a healthy varied diet, use of fortified foods, and use of supplements.

- There is a need for regulation of YCF in order to avoid inappropriate composition.

- Based on the limited data there is no evidence to recommend a composition of YCF that differs from that of follow on formula for energy, iron, vitamin D, n-3 PUFAs, while the protein content should aim towards the lower end of the permitted range if animal protein is used.

- Marketing of YCF should be clearly separated from infant and follow-on formula and the use of similar branding (whether images or text) on these different product categories should be discouraged.

- Future studies are needed to further investigate the role of YCF in the diet of young children. 


\section{References}

1. European Food Safety Authority (EFSA). REPORT FROM THE COMMISSION TO THE EUROPEAN PARLIAMENT AND THE COUNCIL on young-child formulae, 2016. Available at: eur-lex.europa.eu/legalcontent/EN/TXT/PDF/?uri=CELEX:52016DC0169\&from=EN.

2. Przyrembel H, Agostoni C. Growing-up milk: a necessity or marketing? World Rev Nutr Diet 2013;108:49-55.

3. Bundesinstitut für Risikobewertung, 2014, Kindermilch - Abschlussbericht.

4. Böhles HJ, Jochum F, Kauth T, et al. Aktualisierte Empfehlungen zu Folgenahrungen für Kleinkinder im Alter von 1-3 Jahren (sog. Kindermilchgetränke). Monatsschr Kinderheild. 2017; in press.

5. Bocquet A, Bresson JL, Briend A, et al. Alimentation du nourrisson et del'enfant en bas âge - Réalisation pratique. Archives de pédiatrie. 2003;10(1):76-81.

6. Vandenplas Y, De Ronne N, Van De Sompel A, et al. A Belgian consensus-statement on growing-up milks for children 12-36 months old. Eur J Pediatr 2014;173:1365-71.

7. European Food Safety Authority (EFSA). Panel on dietetic products, nutrition and allergies. Scientific opinion on nutrient requirements and dietary intakes of infants and young children in the European Union. EFSA Journal 2013;11:3408.

8. Suthutvoravut U, Abiodun PO, Chomtho S, et al. Composition of Follow-Up Formula for Young Children Aged 12-36 Months: Recommendations of an International Expert Group Coordinated by the Nutrition Association of Thailand and the Early Nutrition Academy. Ann Nutr Metab 2015;67:119-32.

9. Lippman HE, Desjeux JF, Ding ZY, et al. Nutrient Recommendations for Growing-up Milk: A Report of an Expert Panel. Crit Rev Food Sci Nutr 2016;56:141-5. 
10. Ghisolfi J, Fantino M, Turck D, de Courcy GP, Vidailhet M. Nutrient intakes of children aged 1-2 years as a function of milk consumption, cows' milk or growing-up milk. Public Health Nutr 2013;16:524-34.

11. Kristiansen AL, Laugsand Lillegaard IT, Frost Andersen L. Effect of changes in a food frequency questionnaire: comparing data from two national dietary survey instruments among 12-month-old infants. BMC Public Health 2013;13:680.

12. Kristiansen AL, Lillegaard IT, Lande B, Andersen LF. Effect of changes in an FFQ: comparing data from two national dietary survey instruments among 2-year-olds. Br J Nutr 2013;109:363-9.

13. Walton J, Flynn A. Nutritional adequacy of diets containing growing up milks or unfortified cow's milk in Irish children (aged 12-24 months). Food Nutr Res 2013;57:

14. Hay G, Trygg K, Whitelaw A, Johnston C, Refsum H. Folate and cobalamin status in relation to diet in healthy 2-y-old children. Am J Clin Nutr 2011;93:727-35.

15. Huysentruyt K, Laire D, Van Avondt T, De Schepper J, Vandenplas Y. Energy and macronutrient intakes and adherence to dietary guidelines of infants and toddlers in Belgium. Eur J Nutr 2016;55:1595-604.

16. Braegger C, Campoy C, Colomb V, et al. Vitamin D in the healthy European paediatric population. J Pediatr Gastroenterol Nutr 2013;56:692-701.

17. European Food Safety Authority (EFSA) Panel on Dietetic Products, Nutrition and Allergies (NDA): Scientific opinion on the essential composition of infant and followon formulae. EFSA J 2014;12:3760. 
18. AINIA, Centro Tecnológico, 2013, Report of "data collection with respect to the availability and nutritional composition of different types of milk-based drinks and similar products for young children with the denomination of "growing up milks" or "toddlers' milks" or with similar terminology currently on the market in EU Member States", EFSA supporting publication 2013:EN-505.

19. European Food Safety Authority (EFSA) Panel on Dietetic Products, Nutrition and Allergies (NDA). Scientific Opinion on the safety and suitability for use by infants of follow-on formulae with a protein content of at least $1.6 \mathrm{~g} / 100 \mathrm{kcal}$. EFSA Journal 2017;15(5):4781:29. .

20. EFSA Panel on Dietetic Products, Nutrition and Allergies (NDA). Scientific Opinion on the essential composition of infant and follow-on formulae. EFSA Journal 2014;12(7):3760.

21. Hornell A, Lagstrom H, Lande B, Thorsdottir I. Protein intake from 0 to 18 years of age and its relation to health: a systematic literature review for the 5th Nordic Nutrition Recommendations. Food Nutr Res 2013;57:

22. Patro-Golab B, Zalewski BM, Kouwenhoven SM, et al. Protein Concentration in Milk Formula, Growth, and Later Risk of Obesity: A Systematic Review. J Nutr 2016;146:551-64.

23. Scientific Committee for Food, 1993, Report on the essential requirements for infant formulae and follow-on formulae, 34th series, 9, http://ec.europa.eu/food/safety/docs/labelling_nutritionspecial_groups_food-childrenscf_reports 34 en.pdf.

24. Huybrechts I, De Henauw S. Energy and nutrient intakes by pre-school children in Flanders-Belgium. Br J Nutr 2007;98:600-10. 
25. Brand-Miller J, Atkinson F, Rowan A. Effect of added carbohydrates on glycemic and insulin responses to children's milk products. Nutrients 2013;5:23-31.

26. Mis NF, Braegger C, Bronsky J, et al. Sugar in Infants, Children and Adolescents: A Position Paper of the European Society for Paediatric Gastroenterology, Hepatology and Nutrition Committee on Nutrition. J Pediatr Gastroenterol Nutr 2017;

27.

https://www.google.hr/url?sa=t\&rct=j\&q=\&esrc=s\&source=web\&cd=2\&ved= 0ahUKEwjj1PrhqsvSAhWjYpoKHaZ_BpQQFgghMAE\&url=http\%3A\%2F\%2Fwww fao.org $\% 2$ Ffao-who-codexalimentarius $\% 2$ Fsh-

proxy\%2Ffr\%2F\%3Flnk\%3D1\%26url\%3Dhttps\%25253A\%25252F\%25252Fworkspa ce.fao.org\%25252Fsites\%25252Fcodex \%25252FMeetings \%25252FCX-72038\%25252FReport\%25252FFINAL\%25252FREP17_NFSDUe.pdf\&usg=AFQjCNGI clGnv-7aF9AFcrsW85xyq0FbSQ\&sig2=a8s94VAIrpsKOa5NJwKkxg\&cad=rja.

28. Hower J, Knoll A, Ritzenthaler KL, Steiner C, Berwind R. Vitamin D fortification of growing up milk prevents decrease of serum 25-hydroxyvitamin D concentrations during winter: a clinical intervention study in Germany. Eur J Pediatr 2013;172:1597605.

29. Szymlek-Gay EA, Ferguson EL, Heath AL, Gray AR, Gibson RS. Food-based strategies improve iron status in toddlers: a randomized controlled trial12. Am J Clin Nutr 2009;90:1541-51.

30. Houghton LA, Gray AR, Szymlek-Gay EA, Heath AL, Ferguson EL. Vitamin Dfortified milk achieves the targeted serum 25-hydroxyvitamin D concentration without affecting that of parathyroid hormone in New Zealand toddlers. J Nutr 2011;141:18406. 
31. Morgan EJ, Heath AL, Szymlek-Gay EA, et al. Red meat and a fortified manufactured toddler milk drink increase dietary zinc intakes without affecting zinc status of New Zealand toddlers. J Nutr 2010;140:2221-6.

32. Akkermans MD, Eussen SR, van der Horst-Graat JM, et al. A micronutrient-fortified young-child formula improves the iron and vitamin D status of healthy young European children: a randomized, double-blind controlled trial. Am J Clin Nutr 2017;105:391-399.

33. Misra S, Khor GL, Mitchell P, Haque S, Benton D. A pilot study to determine the short-term effects of milk with differing glycaemic properties on sleep among toddlers: a randomised controlled trial. BMC Pediatr 2015;15:79.

34. Xuan NN, Wang D, Grathwohl D, et al. Effect of a Growing-up Milk Containing Synbiotics on Immune Function and Growth in Children: A Cluster Randomized, Multicenter, Double-blind, Placebo Controlled Study. Clin Med Insights Pediatr 2013;7:49-56.

35. Chatchatee P, Lee WS, Carrilho E, et al. Effects of growing-up milk supplemented with prebiotics and LCPUFAs on infections in young children. J Pediatr Gastroenterol Nutr 2014;58:428-37.

36. Cairncross CT, Stonehouse W, Conlon CA, et al. Predictors of vitamin D status in New Zealand preschool children. Matern Child Nutr 2016;

37. Vieux F, Brouzes CM, Maillot M, et al. Role of Young Child Formulae and Supplements to Ensure Nutritional Adequacy in U.K. Young Children. Nutrients 2016;8:

38. Matsuyama M, Harb T, David M, Davies PS, Hill RJ. Effect of fortified milk on growth and nutritional status in young children: a systematic review and metaanalysis. Public Health Nutr 2016;1-12. 
39. Pereira C, Ford R, Feeley AB, et al. Cross-sectional survey shows that follow-up formula and growing-up milks are labelled similarly to infant formula in four low and middle income countries. Matern Child Nutr 2016;12 Suppl 2:91-105.

40. World Health Organization, UNICEF, IBFAN. Marketing of breast-milk substitutes: National implementation of the international code Status Report 2016. Available at: http://www.who.int/nutrition/publications/infantfeeding/code_report2016/en/.

41. World Health Organization. International Code of Marketing of Breast-milk Substitutes. Geneva, 1981.

42. Bocquet A, Vidailhet M. Nutri-Bebe 2013 Study Part 2. How do French mothers feed their young children? Arch Pediatr 2015;22:10S7-10S19.

43. Grimes CA, Szymlek-Gay EA, Campbell KJ, Nicklas TA. Food Sources of Total Energy and Nutrients among U.S. Infants and Toddlers: National Health and Nutrition Examination Survey 2005-2012. Nutrients 2015;7:6797-836.

44. Scott J, Davey K, Ahwong E, et al. A Comparison by Milk Feeding Method of the Nutrient Intake of a Cohort of Australian Toddlers. Nutrients 2016;8:

45. Yu P, Denney L, Zheng Y, et al. Food groups consumed by infants and toddlers in urban areas of China. Food Nutr Res 2016;60:30289.

46. Eussen SR, Pean J, Olivier L, Delaere F, Lluch A. Theoretical Impact of Replacing Whole Cow's Milk by Young-Child Formula on Nutrient Intakes of UK Young Children: Results of a Simulation Study. Ann Nutr Metab 2015;67:247-56. 


\begin{tabular}{|c|c|c|c|c|c|c|}
\hline Nutrient & $\begin{array}{l}\text { Units for } \\
\text { first } 4 \\
\text { columns }\end{array}$ & YCF, median (min-max) & $\begin{array}{c}\text { YCF, cow's milk } \\
\text { based, median (P5- } \\
\text { P95) }\end{array}$ & $\begin{array}{l}\text { Full fat cow's milk, } \\
\text { mean }\end{array}$ & $\begin{array}{l}\text { EFSA } \\
\text { recommendation } \\
\text { for follow-on } \\
\text { formula min-max or } \\
\text { min }\end{array}$ & $\begin{array}{l}\text { EFSA report on the } \\
\text { total daily } \\
\text { requirements for } \\
\text { children 1-3 } \\
\text { years/day }\end{array}$ \\
\hline Energy & $\mathrm{kcal} / 100 \mathrm{~g}$ & $67(50-81)$ & $67(50-81)$ & 69 & $60-70$ & \\
\hline Protein & $\mathrm{g} / 100 \mathrm{kcal}$ & $2.6(2-6.7)$ & $2.6(2.1-3.6)$ & 4.8 & $1.6-2.5$ & $10-13 \mathrm{~g} /$ day \\
\hline Casein & $\mathrm{g} / 100 \mathrm{kcal}$ & $1.7(0.1-2.4)$ & NR & NR & +2 & \\
\hline Whey Protein & $\mathrm{g} / 100 \mathrm{kcal}$ & $0.7(0.4-1.2)$ & NR & NR & & \\
\hline Carbohydrates & $\mathrm{g} / 100 \mathrm{kcal}$ & $12.6(7.3-15.4)$ & $12.6(11.1-14.3)$ & 6.8 & $9-14$ & $45-50 \% \mathrm{E}$ \\
\hline Total sugars & & $9.9(3.1-13.7)$ & NR & NR & $\begin{array}{l}<20 \% \text { of total } \\
\text { carbohydrates }\end{array}$ & $\begin{array}{l}<10 \% \text { of } \\
\text { carbohydrates }\end{array}$ \\
\hline Lactose & $\mathrm{g} / 100 \mathrm{kcal}$ & $9(0.1-13.5)$ & NR & NR & $>4.5$ & \\
\hline Sucrose & $\mathrm{g} / 100 \mathrm{kcal}$ & $2.1(0.6-10.4)$ & NR & NR & NR & \\
\hline Glucose & $\mathrm{g} / 100 \mathrm{kcal}$ & $0.5(0-1.8)$ & NR & NR & 0 & \\
\hline Maltose & $\mathrm{g} / 100 \mathrm{kcal}$ & $0.2(0.1-5)$ & NR & NR & NR & \\
\hline Maltodextrin & $\mathrm{g} / 100 \mathrm{kcal}$ & $4.1(1.4-11.2)$ & NR & NR & NR & \\
\hline Fibre & $\mathrm{g} / 100 \mathrm{kcal}$ & $0.8(0-2.4)$ & $\mathrm{NR}$ & NR & NR & $10 \mathrm{~g}$ \\
\hline Fat & $\mathrm{g} / 100 \mathrm{kcal}$ & $4.3(3-5.7)$ & $4.3(3.5-4.8)$ & 6.1 & 4.4-6 & $35-40 \% \mathrm{E}$ \\
\hline Saturated Fat & $\mathrm{g} / 100 \mathrm{kcal}$ & $1.4(0.2-4.3)$ & $1.4(0.4-2.1)$ & NR & & \\
\hline Monounsaturated & $\mathrm{g} / 100 \mathrm{kcal}$ & $1.9(0.7-3)$ & NR & NR & & \\
\hline Polyunsaturated & $\mathrm{g} / 100 \mathrm{kcal}$ & $0.9(0.4-3.4)$ & NR & NR & & \\
\hline Linoleic Acid n-6 & $\mathrm{g} / 100 \mathrm{kcal}$ & $0.8(0.1-2.4)$ & $0.75(0.5-1.04)$ & 0.07 & $0.5-1.2$ & $4 \% \mathrm{E}$ \\
\hline $\begin{array}{l}\text { Arachidonic Acid } \\
\text { (ARA) }\end{array}$ & $\mathrm{g} / 100 \mathrm{kcal}$ & $0(0-0.2)$ & $4.1(1.1-14.3)$ & 0 & & \\
\hline $\begin{array}{l}\text { Alpha Linolenic Acid } \\
n-3\end{array}$ & $\begin{array}{l}\mathrm{mg} / 100 \\
\mathrm{kcal}\end{array}$ & $103(0-589.2)$ & $103(57.6-169.0)$ & 0 & $50-100$ & $0.5 \% \mathrm{E}$ \\
\hline $\begin{array}{l}\text { Eicosapentaenoic } \\
\text { acid (EPA) }\end{array}$ & $\begin{array}{l}\mathrm{mg} / 100 \\
\mathrm{kcal}\end{array}$ & $19(11.8-81.8)$ & NR & NR & & $\begin{array}{l}\text { DHA } 100(<24 \\
\text { months) }\end{array}$ \\
\hline $\begin{array}{l}\text { Docosahexaenoic } \\
\text { acid (DHA) }\end{array}$ & $\begin{array}{l}\mathrm{mg} / 100 \\
\mathrm{kcal}\end{array}$ & $6.4(0.4-42.6)$ & $6.4(2.2-22.3)$ & NR & $20-50$ & $\begin{array}{l}\text { DHA + EPA } 250 \\
\text { (>24 months) }\end{array}$ \\
\hline
\end{tabular}

Copyright @ ESPGHAN and NASPGHAN. All rights reserved. 


\begin{tabular}{|c|c|c|c|c|c|c|}
\hline Trans fatty acids & & NR & NR & NR & $<3 \%$ total fatty acid & \\
\hline \multicolumn{7}{|l|}{ Minerals } \\
\hline Sodium & $\begin{array}{l}\mathrm{mg} / 100 \\
\mathrm{kcal}\end{array}$ & 40.4 (15.9-85.7) & $40.3(27.6-57.1)$ & 64.3 & 25 & $170-370 \mathrm{mg}$ \\
\hline Potassium & $\begin{array}{l}\mathrm{mg} / 100 \\
\mathrm{kcal}\end{array}$ & 126.8 (85.9-322.9) & $127.0(101.0-199.0)$ & 215.1 & 80 & $800 \mathrm{mg}$ \\
\hline Chloride & $\begin{array}{l}\mathrm{mg} / 100 \\
\mathrm{kcal}\end{array}$ & 75 (14.1-166.2) & $75.0(61.2-114.0)$ & 146.5 & 60 & $270-570 \mathrm{mg}$ \\
\hline Calcium & $\begin{array}{l}\mathrm{mg} / 100 \\
\mathrm{kcal}\end{array}$ & $126.9(77.1-270.8)$ & $127.0(94.4-220.0)$ & 176.7 & 50 & $600 \mathrm{mg}$ \\
\hline Phosphorus & $\begin{array}{l}\mathrm{mg} / 100 \\
\mathrm{kcal}\end{array}$ & 77.6 (46.4-185.7) & 77.3 (58.4-134.0) & 138.3 & 25 & $450 \mathrm{mg}$ \\
\hline Magnesium & $\begin{array}{l}\mathrm{mg} / 100 \\
\mathrm{kcal}\end{array}$ & $10.4(6.6-49)$ & $10.4(8.1-20.0)$ & 16.8 & 5 & $85 \mathrm{mg}$ \\
\hline \multicolumn{7}{|l|}{ Trace elements } \\
\hline Iron & $\begin{array}{l}\mathrm{mg} / 100 \\
\mathrm{kcal}\end{array}$ & $1.8(1-2.9)$ & $1.8(1.3-2.4)$ & $<0.1$ & 0.6 & $8 \mathrm{mg}$ \\
\hline Zinc & $\begin{array}{l}\mathrm{mg} / 100 \\
\mathrm{kcal}\end{array}$ & $1.1(0.1-3)$ & $1.2(0.7-2.0)$ & 0.6 & 0.5 & $4 \mathrm{mg}$ \\
\hline Copper & $\begin{array}{l}\mathrm{mg} / 100 \\
\mathrm{kcal}\end{array}$ & $0.1(0-0.1)$ & $61.5(35.0-118.0)$ & 0 & 0.06 & $0.4 \mathrm{mg}$ \\
\hline Manganese & $\begin{array}{l}\mathrm{mg} / 100 \\
\mathrm{kcal}\end{array}$ & $0(0-1)$ & $0.01(0.006-0.1)$ & 0 & 1 & $0.5 \mathrm{mg}$ \\
\hline Fluoride & $\begin{array}{l}\mathrm{mg} / 100 \\
\mathrm{kcal}\end{array}$ & $0(0-0.1)$ & NR & NR & NN & $0.6 \mathrm{mg}$ \\
\hline Selenium & $\mu \mathrm{g} / 100 \mathrm{kcal}$ & $2.4(1-6.7)$ & $1.6(1.4-5.5)$ & 1.9 & 3 & $20 \mu \mathrm{g}$ \\
\hline lodine & $\mu \mathrm{g} / 100 \mathrm{kcal}$ & $20(0-54)$ & $20.2(12.2-34.8)$ & 23 & 15 & $90 \mu \mathrm{g}$ \\
\hline Chromium & $\mu \mathrm{g} / 100 \mathrm{kcal}$ & $1.4(1.4-1.5)$ & NR & NR & NN & - \\
\hline Molybdenum & $\mu \mathrm{g} / 100 \mathrm{kcal}$ & $4.2(4.1-4.4)$ & NR & NR & 0.4 & $15 \mu \mathrm{g}$ \\
\hline Vitamins & & 7 & & & & \\
\hline Vitamin A & $\mu \mathrm{g} / 100 \mathrm{kcal}$ & $101.6(9.6-176.3)$ & $102.0(77.8-141.0)$ & 57.5 & 70 & $400 \mu \mathrm{g}$ \\
\hline
\end{tabular}

Copyright @ ESPGHAN and NASPGHAN. All rights reserved. 


\begin{tabular}{|c|c|c|c|c|c|c|}
\hline Vitamin D & $\mu \mathrm{g} / 100 \mathrm{kcal}$ & $2.1(0.9-6)$ & $2.1(1.4-3.3)$ & 0.1 & 2 & $10 \mu g$ \\
\hline Vitamin E & $\begin{array}{l}\mathrm{mg} / 100 \\
\mathrm{kcal}\end{array}$ & $1.6(0-7)$ & $1.6(0.9-3.1)$ & 0.1 & 0.6 & $6 \mathrm{mg}$ \\
\hline Vitamin K & $\mu \mathrm{g} / 100 \mathrm{kcal}$ & 7.5 (0-16.3) & $7.5(4.5-11.8)$ & 0 & 1 & $12 \mu \mathrm{g}$ \\
\hline Vitamin $B_{1}$ (Thiamin) & $\begin{array}{l}\mathrm{mg} / 100 \\
\mathrm{kcal}\end{array}$ & $0.1(0-1.2)$ & $0.12(0.07-0.27)$ & 0 & 0.04 & $0.5 \mathrm{mg}$ \\
\hline $\begin{array}{l}\text { Vitamin } \mathrm{B}_{2} \\
\text { (Riboflavin) }\end{array}$ & $\begin{array}{l}\mathrm{mg} / 100 \\
\mathrm{kcal}\end{array}$ & $0.2(0-1.2)$ & $0.20(0.14-0.35)$ & 0.3 & 0.06 & $0.8 \mathrm{mg}$ \\
\hline Vitamin $B_{3}$ (Niacin) & $\begin{array}{l}\mathrm{mg} / 100 \\
\mathrm{kcal}\end{array}$ & $0.9(0-4.1)$ & $0.90(0.57-3.1)$ & 1.0 & 0.4 & $9 \mathrm{mg}$ \\
\hline $\begin{array}{l}\text { Vitamin } \mathrm{B}_{5} \\
\text { (Pantothenic acid) }\end{array}$ & $\begin{array}{l}\mathrm{mg} / 100 \\
\mathrm{kcal}\end{array}$ & $0.7(0-6.8)$ & $0.71(0.42-1.3)$ & 0.6 & 0.4 & $4 \mathrm{mg}$ \\
\hline $\begin{array}{l}\text { Vitamin } B_{6} \\
\text { (Pyridoxine) }\end{array}$ & $\begin{array}{l}\mathrm{mg} / 100 \\
\mathrm{kcal}\end{array}$ & $0.1(0-0.7)$ & $0.1(0.06-0.3)$ & 0 & 0.02 & $0.7 \mathrm{mg}$ \\
\hline Vitamin $B_{7}$ (Biotin) & $\mu \mathrm{g} / 100 \mathrm{kcal}$ & $3.1(0-7.5)$ & $3.1(2.2-6.6)$ & 4.3 & 1 & $20 \mu \mathrm{g}$ \\
\hline $\begin{array}{l}\text { Vitamin } \mathrm{B}_{9} \\
\text { (Folic Acid) }\end{array}$ & $\mu \mathrm{g} / 100 \mathrm{kcal}$ & $22.4(0-42.2)$ & $22.4(7.3-38.6)$ & 9.1 & 15 & $100 \mu \mathrm{g}$ \\
\hline $\begin{array}{l}\text { Vitamin } \mathrm{B}_{12} \\
\text { (Cobalamine) }\end{array}$ & $\begin{array}{l}\mathrm{mg} / 100 \\
\mathrm{kcal}\end{array}$ & $0.3(0-0.9)$ & $0.27(0.18-0.59)$ & 0.7 & 0.1 & $0.9 \mathrm{mg}$ \\
\hline Vitamin C & $\begin{array}{l}\mathrm{mg} / 100 \\
\mathrm{kcal}\end{array}$ & $15.4(2.2-34.8)$ & $15.9(8.7-23.4)$ & 1.9 & 4 & $20 \mathrm{mg}$ \\
\hline
\end{tabular}

Table 1. Composition of young child formulae present on the European market, compared to the composition of cow's milk and recommended composition of follow-on formula. Recommended nutritional intakes for toddlers (EFSA and AINIA report) are also provided $(1,7,17-19)$; E- energy, NN not necessary, NR - not reported. 


\begin{tabular}{|c|c|c|c|c|c|c|c|}
\hline $\begin{array}{l}\text { Author, } \\
\text { year }\end{array}$ & Country & $\begin{array}{l}\text { Subjects, } \\
\text { age }\end{array}$ & $\begin{array}{l}\text { Type of } \\
\text { the study }\end{array}$ & $\begin{array}{l}\text { Active and } \\
\text { comparison }\end{array}$ & Objective & Results & Industry sponsored \\
\hline $\begin{array}{l}\text { Akkermans } \\
(2017)(32)\end{array}$ & $\begin{array}{l}\text { Germany, } \\
\text { Netherlands, } \\
\text { United } \\
\text { Kingdom }\end{array}$ & $\begin{array}{l}318(1-3 \\
\text { years })\end{array}$ & $\mathrm{RCT}$ & $\begin{array}{l}\text { YCF vs non-fortified } \\
\text { cow's milk }\end{array}$ & $\begin{array}{l}\text { Ferritin and } \\
\text { vitamin D levels }\end{array}$ & $\begin{array}{l}\text { Iron and vitamin D deficiency } \\
\text { was lower in YCF group; } \\
\text { significant increase in serum } \\
\text { ferritin and vitamin D levels in } \\
\text { YCF group }\end{array}$ & $\begin{array}{l}\text { Supported by Danone } \\
\text { Nutricia Research }\end{array}$ \\
\hline $\begin{array}{l}\text { Chatchatee } \\
(2014)(35)\end{array}$ & Malaysia & $\begin{array}{l}767 \text { (14-24 } \\
\text { months) }\end{array}$ & $\mathrm{RCT}$ & $\begin{array}{l}\text { YCF with } \\
\text { scGOS/IcFOS/LCPUFAs } \\
\text { vs YCF }\end{array}$ & Infection rate & $\begin{array}{l}\text { Decreased risk of developing at } \\
\text { least } 1 \text { infection }\end{array}$ & $\begin{array}{l}3 \text { authors are } \\
\text { employees of Nutricia } \\
\text { Research }\end{array}$ \\
\hline $\begin{array}{l}\text { Houghton } \\
(2011)(30)\end{array}$ & $\begin{array}{l}\text { New } \\
\text { Zealand }\end{array}$ & $\begin{array}{l}225 \text { (12-20 } \\
\text { months) }\end{array}$ & $\mathrm{RCT}$ & $\begin{array}{l}\text { Red meat vs } \\
\text { micronutrient- } \\
\text { fortified cow milk vs } \\
\text { vitamin D fortified } \\
\text { cow milk (both milks } \\
\text { had vit D) }\end{array}$ & $\begin{array}{l}\text { The effect of } \\
\text { vitamin D- } \\
\text { fortified milk on } \\
\text { serum } \\
\text { 25(OH)D and PTH }\end{array}$ & $\begin{array}{l}\text { Increase in vitamin D in fortified } \\
\text { milks, PTH was same }\end{array}$ & $\begin{array}{l}\text { No; } \\
\text { Heinz Wattie's New } \\
\text { Zealand Ltd provided } \\
\text { the micronutrient- } \\
\text { fortified milk. } \\
\text { Fonterra New Zealand } \\
\text { Ltd provided the } \\
\text { vitamin D-fortified milk. }\end{array}$ \\
\hline $\begin{array}{l}\text { Hower } \\
(2013)(28)\end{array}$ & Germany & $\begin{array}{l}92(2-6 \\
\text { years })\end{array}$ & $\mathrm{RCT}$ & $\begin{array}{l}\text { Vitamin D fortified } \\
\text { GUM vs non semi } \\
\text { skimmed regular mi }\end{array}$ & Vitamin D status & $\begin{array}{l}\text { Daily consumption of fortified } \\
\text { growing up milk contributed to } \\
\text { the prevention of an otherwise } \\
\text { frequently observed decrease in } \\
\text { serum vit D concentration } \\
\text { during winter } \\
\text { Frequency of infection was } \\
\text { similar }\end{array}$ & $\begin{array}{l}\text { The study was funded } \\
\text { by HiPP GmbH and Co. }\end{array}$ \\
\hline $\begin{array}{l}\text { Misra } \\
(2015)(33)\end{array}$ & Malaysia & $\begin{array}{l}88 \\
\text { toddlers }\end{array}$ & $\mathrm{RCT}$ & $\begin{array}{l}\text { High vs low GI } \\
\text { formula }\end{array}$ & Sleep pattern & NS & $\begin{array}{l}\text { This research was } \\
\text { funded by Fonterra Co- } \\
\text { operative Group Limited }\end{array}$ \\
\hline $\begin{array}{l}\text { Morgan } \\
(2010)(31)\end{array}$ & $\begin{array}{l}\text { New } \\
\text { Zealand }\end{array}$ & $\begin{array}{l}225 \text { (12-20 } \\
\text { months) }\end{array}$ & $\mathrm{RCT}$ & $\begin{array}{l}\text { Red meat vs fortified } \\
\text { cow milk vs non } \\
\text { fortified cow milk }\end{array}$ & $\begin{array}{l}\text { The effect on zinc } \\
\text { status }\end{array}$ & $\begin{array}{l}\text { No increase in serum zinc in all } \\
\text { groups }\end{array}$ & $\begin{array}{l}\text { No; } \\
\text { Heinz Wattie's New } \\
\text { Zealand Ltd provided } \\
\text { the fortified milk; }\end{array}$ \\
\hline
\end{tabular}

Copyright @ ESPGHAN and NASPGHAN. All rights reserved. 


\begin{tabular}{|c|c|c|c|c|c|c|c|}
\hline & & & & & & & $\begin{array}{l}\text { Fonterra New Zealand } \\
\text { provided the non- } \\
\text { fortified milk; Canpac } \\
\text { International Ltd } \\
\text { donated the cans and } \\
\text { spoons; and Fisher and } \\
\text { Paykel Appliances Ltd } \\
\text { donated a freezer. }\end{array}$ \\
\hline $\begin{array}{l}\text { Szymlek- } \\
\text { Gay (2009) } \\
(29)\end{array}$ & $\begin{array}{l}\text { New } \\
\text { Zealand }\end{array}$ & $\begin{array}{l}225(1-3 \\
\text { years })\end{array}$ & $\mathrm{RCT}$ & $\begin{array}{l}\text { Red meat, iron } \\
\text { fortified toddlers milk, } \\
\text { regular cow milk }\end{array}$ & Iron status & $\begin{array}{l}\text { Consumption of iron-fortified } \\
\text { toddlers' milk can increase iron } \\
\text { stores in healthy non-anemic } \\
\text { toddlers, whereas increased } \\
\text { intakes of red meat can prevent } \\
\text { their decline. }\end{array}$ & $\begin{array}{l}\text { No; } \\
\text { Heinz Wattie's New } \\
\text { Zealand Ltd provided } \\
\text { the iron-fortified milk; } \\
\text { Fonterra New Zealand } \\
\text { provided the } \\
\text { nonfortified milk; } \\
\text { Canpac International } \\
\text { Ltd donated the cans } \\
\text { and spoons; and Fisher } \\
\text { and Paykel Appliances } \\
\text { Ltd donated a freezer. }\end{array}$ \\
\hline $\begin{array}{l}\text { Xuan } \\
(2013)(34)\end{array}$ & Vietnam & $\begin{array}{l}368 \text { (18-36 } \\
\text { months) }\end{array}$ & $\begin{array}{l}\text { cluster } \\
\text { RCT }\end{array}$ & $\begin{array}{l}\text { YCF supplemented } \\
\text { with synbiotics ( } L \text {. } \\
\text { paracasei NCC2461 } \\
\text { and } B \text {. longum } \\
\text { NCC } 3001 \text {; inulin and } \\
\text { FOS) and vitamins (A, } \\
\text { C, and E), minerals } \\
\text { (zinc and selenium), } \\
\text { and DHA vs regular } \\
\text { YCF }\end{array}$ & $\begin{array}{l}\text { IgA, growth, } \\
\text { nutritional status } \\
\text { (anemia, zinc, } \\
\text { and vitamin A } \\
\text { deficiencies), } \\
\text { infection rate }\end{array}$ & $\begin{array}{l}\text { Increase in IgA, NS for all other } \\
\text { outcomes }\end{array}$ & $\begin{array}{l}\text { The study was } \\
\text { supported by a Nestlé } \\
\text { research fund. }\end{array}$ \\
\hline
\end{tabular}

Copyright @ ESPGHAN and NASPGHAN. All rights reserved. 


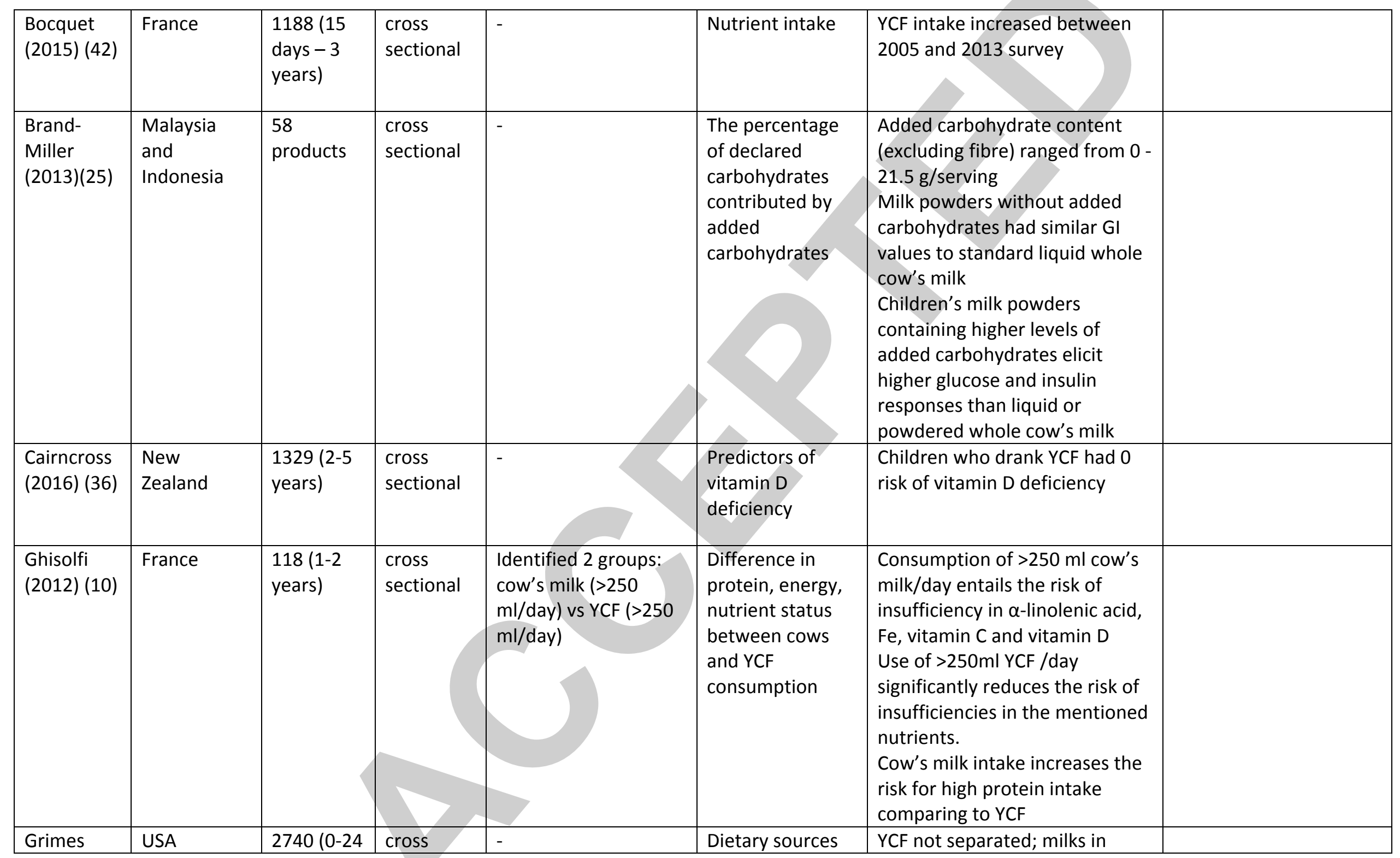

Copyright @ ESPGHAN and NASPGHAN. All rights reserved. 


\begin{tabular}{|c|c|c|c|c|c|c|c|}
\hline (2015) (43) & & months) & sectional & & & $\begin{array}{l}\text { general contributed as a main } \\
\text { macronutrients source }\end{array}$ & \\
\hline $\begin{array}{l}\text { Pereira } \\
(2016)(39)\end{array}$ & $\begin{array}{l}\text { Cambodia, } \\
\text { Nepal, } \\
\text { Senegal, } \\
\text { Cambodia }\end{array}$ & $\begin{array}{l}\text { Not } \\
\text { mentioned }\end{array}$ & $\begin{array}{l}\text { cross } \\
\text { sectional }\end{array}$ & - & $\begin{array}{l}\text { Characteristics of } \\
\text { labels of follow- } \\
\text { on formula and } \\
\text { YCF } \\
\text { compared with } \\
\text { infant formula }\end{array}$ & $\begin{array}{l}20-85 \% \text { had similar } \\
\text { slogans/mascots/symbols }\end{array}$ & \\
\hline $\begin{array}{l}\text { Scott } \\
(2016)(44)\end{array}$ & Australia & $\begin{array}{l}832(1 \\
\text { year })\end{array}$ & $\begin{array}{l}\text { cross } \\
\text { sectional }\end{array}$ & - & $\begin{array}{l}\text { Contribution of } \\
\text { breastmilk and } \\
\text { infant formula to } \\
\text { the nutritional } \\
\text { intake of toddlers }\end{array}$ & $\begin{array}{l}4 \% \text { received YCF ( } 53 \% \text { still } \\
\text { received infant formula) } \\
\text { Iron intake was below } \\
\text { recommendation in half of } \\
\text { breastfed and quarter of } \\
\text { formula fed toddlers }\end{array}$ & \\
\hline $\begin{array}{l}\text { Vieux } \\
(2016)(37)\end{array}$ & $\begin{array}{l}\text { United } \\
\text { Kingdom }\end{array}$ & $\begin{array}{l}1147(12- \\
18 \\
\text { months) }\end{array}$ & $\begin{array}{l}\text { computer } \\
\text { modelling } \\
\text { study } \\
\text { using } \\
\text { cross- } \\
\text { sectional } \\
\text { data } \\
\end{array}$ & - & $\begin{array}{l}\text { Dietary changes } \\
\text { needed to ensure } \\
\text { nutritional } \\
\text { adequacy }\end{array}$ & $\begin{array}{l}\text { Increasing YCF and supplement } \\
\text { consumption was the shortest } \\
\text { way to cover nutrient } \\
\text { requirements }\end{array}$ & \\
\hline $\begin{array}{l}\text { Walton } \\
\text { (2013) (13) }\end{array}$ & Ireland & $\begin{array}{l}85(12-24 \\
\text { years })\end{array}$ & $\begin{array}{l}\text { cross } \\
\text { sectional }\end{array}$ & $\begin{array}{l}\text { Identified } 2 \text { groups: at } \\
\text { least } 300 \text { g and } \\
\text { consuming YCF ( }>100 \\
\text { g/day) together with } \\
\text { cow's milk } \\
\text { or cow's milk only }\end{array}$ & $\begin{array}{l}\text { Nutritional } \\
\text { adequacy of two } \\
\text { groups }\end{array}$ & $\begin{array}{l}\text { Consumption of YCF reduced } \\
\text { the risk of inadequacies of iron } \\
\text { and vitamin D }\end{array}$ & \\
\hline $\begin{array}{l}\text { Yu (2016) } \\
(45)\end{array}$ & China & $\begin{array}{l}914 \text { (12-35 } \\
\text { months) }\end{array}$ & $\begin{array}{l}\text { cross } \\
\text { sectional }\end{array}$ & - & $\begin{array}{l}\text { Feeding patterns } \\
\text { in infants and } \\
\text { toddlers }\end{array}$ & App 50\% received YCF & \\
\hline $\begin{array}{l}\text { Eussen } \\
(2015)(46)\end{array}$ & $\begin{array}{l}\text { United } \\
\text { Kingdom }\end{array}$ & $\begin{array}{l}1275(12- \\
18 \\
\text { months) }\end{array}$ & $\begin{array}{l}\text { Simulation } \\
\text { study }\end{array}$ & $\begin{array}{l}\text { Data extracted from } \\
\text { the DNSIYC registry; } \\
\text { two scenarios where }\end{array}$ & $\begin{array}{l}\text { Theoretical } \\
\text { nutritional } \\
\text { impact of }\end{array}$ & $\begin{array}{l}\text { Before simulation } 95.2 \% \text { of } \\
\text { toddlers received inadequate } \\
\text { amount of vitamin D and } 53.8 \%\end{array}$ & \\
\hline
\end{tabular}

Copyright @ ESPGHAN and NASPGHAN. All rights reserved. 


\begin{tabular}{|l|l|l|l|l|l|}
\hline & & $\begin{array}{l}\text { cow's milk was } \\
\text { theoretically replaced } \\
\text { with matching volume } \\
\text { of YCF (Scenario 1) or } \\
\text { 300 ml of YCF } \\
\text { (Scenario 1) }\end{array}$ & $\begin{array}{l}\text { replacing the } \\
\text { cow's milk with }\end{array}$ & $\begin{array}{l}\text { of iron; after simulation } \\
\text { inadequacy decreased to 4.9\% } \\
\text { Yand 0\% for vitamin D and 2.7\% } \\
\text { and 1.1\% for iron }\end{array}$ \\
& & & \\
\hline
\end{tabular}

Table 2. Available evidence; GI - glycaemic index, RCT - randomized controlled trial, YCF - young child formulae.

Copyright $\odot$ ESPGHAN and NASPGHAN. All rights reserved. 